\title{
Les febleses femenines en Giordano da Pisa, Bernardi de Siena $i$ sant Vicent Ferrer
}

\author{
[The feminine vices in Giordano da Pisa, \\ Bernardino da Siena and Vicent Ferrer]
}

\author{
Anna Isabel Peirats Navarro \\ Universidad Católica de Valencia San Vicente Mártir \\ anna.peirats@ucv.es
}

Resum: Aquest article se centra en l'estudi contrastat dels sermons de tres predicadors dels segles XIV i Xv, Giordano da Pisa, Bernardí de Siena i sant Vicent Ferrer, que compartien un mateix objectiu: mostrar les febleses de les dones i, com a conseqüència, remarcar la necessitat d'una conversió espiritual. Els tres predicadors tenen en comú l'ús de la llengua vulgar, encara que presenten el seu missatge amb estils diferents: Da Pisa s'adreça a un públic més culte i expert; Bernardí predica per a tot el poble i pretén arribar a tota la societat, a la qual pretén aconsellar i orientar a la conversió; sant Vicent Ferrer presenta als seus sermons un to més ofensiu i vehement, per tal d'infondre el temor i aconseguir la conversió espiritual.

Paraules clau: predicació, Bernardí de Siena, Giordano da Pisa, Vicent Ferrer, dones, conversió

AвSTRACT: This article focuses on the contrasting study of the sermons of three preachers from the 14th and 15th centuries, Giordano da Pisa, Bernardino of Siena and Vincent Ferrer, who shared the same objective: to show the weaknesses of women and, as a consequence, show the need for a spiritual conversion. The three preachers have in common the use of the vulgar language, although they present their message with different styles: Da Pisa addresses a cultured and expert audience; Bernardino preaches for all the people and tries to reach the whole society, to which he tries to advise and guide the conversion; Vincent Ferrer presents his sermons with a more offensive and vehement tone, in order to instill fear and achieve spiritual conversion.

Keywords: Preaching, Bernardino da Siena, Giordano da Pisa, Vincent Ferrer, women, conversion

Recepció: 26/02/2019. Acceptació: 08/03/2019. Publicació: 05/04/2019

REVISTA VALENCIANA DE FILOLOGIA/I I I (20I9) p. 345-362/ISSN 0556-705X/DOI IO.28939/RVF.V3IO.69 


\section{Introducció}

Un interés vigent ${ }^{1}$ en tots els segles és entendre el sentit de la vida del ser humà en la terra i, doncs, esbrinar si existeix un més enllà després de la mort física. Siga des del punt de vista profà o des de l'àmbit de la religió, la necessitat de respondre a les clàssiques preguntes sobre qui som i on anem ha sigut un punt en què han convergit la teologia, la ciència i la literatura. Tant des de la Sagrada Escriptura i els textos patrístics, com des de les obres didàctiques de la literatura medieval, és recurrent la tendència a argumentar que la salvació espiritual de l'ànima està directament relacionada amb l'exercici d'una vida virtuosa, amb el temor pel dia en què es jutjaran les accions dutes a terme en la terra i s'atorgarà el guardó o el càstig pertinent, sense distincions.

Des dels orígens, el cristianisme sempre ha atorgat especial relleu a la predicació (Murphy 1974), per tal com ha sigut constant la necessitat de predicar i instruir, tot $\mathrm{i}$ que ha anat variant diacrònicament l'estil a partir del qual el predicador pretén adoctrinar i persuadir el receptor sobre els perills del delit carnal. En aquest sentit, tots els sermonadors convergien en un aspecte clau: erradicar en la societat el pecat de la luxúria, que es considerava l'inici de tots els mals del món, tenint en compte la visió devaluadora de la dona, que entronca en la mateixa creació dels primers pares en el jardí de l'Edén, les epístoles de sant Pau, els textos dels sants Pares de l'Església, sense obviar l'evident contribució de la medicina, la filosofia i la literatura.

En aquest punt de partida de desmitificació femenina hem de situar els discursos dels predicadors del segle XIV i Xv que són objecte d'estudi d'aquestes pàgines: Giordano da Pisa, dominicà, amb els sermons del Quaresimale fiorentino (1305-1306), Bernardí de Siena, franciscà, amb Prediche volgari sul campo di Siena (1427) i els sermons del frare dominicà sant Vicent Ferrer (Sanchis i Schib 1932-1988; Sanchis Sivera 1927) que va predicar i infondre per tot arreu la por al Judici Final. A partir de la lectura de les obres anteriorment esmen-

1 Aquest article s'emmarca en el grup d'investigació núm. 188 del Departament de Llengua i Literatura de la Universidad Católica de Valencia.

REVISTA VALENCIANA DE FILOLOGIA / I I I (20I9) p. 345-362

ANNA ISABEL PEIRATS NAVARRO

Les febleses femenines en Giordano da Pisa, Bernardí de Siena i sant Vicent Ferrer / 346 
tades dels tres predicadors, i partint d'una anàlisi comparativa, es parteix de l'objectiu d'estudiar com s'adreçaven a les dones els tres predicadors en els seus sermons, i quina és la consideració atorgada a la figura femenina, així com la visió del matrimoni com a sagrament, i de l'adulteri, com a exponent màxim de la luxúria desenfrenada, a fi de persuadir els receptors sobre la necessitat d'una reforma social, orientada a una vida virtuosa.

\section{La predicació en Giordano da Pisa, Bernardí de Siena i sant Vicent Ferrer}

Des dels primers temps de l'Església, la litúrgia i les festivitats religioses van propiciar nombroses ocasions idònies perquè la forma del sermó anara adquirint rellevància. Mentre el llatí era la llengua viva, els sermons, en llengua vulgar, van representar una modalitat rica i innovadora en la literatura medieval, que va trobar la seua consciència artística de realització en les artes praedicandi. Els nous ordes religiosos, dominics i franciscans, es van servir abundantment del sermó, fet que va propiciar que aquesta prosa oratòria esdevinguera més àgil, eficient i artística. Encara que els sermons, en origen, eren eminentment de caràcter oral, es va dur a terme un acostament progressiu de la prosa oral a l'escrita.

En aquest context cal situar la predicació de Giordano da Pisa, Bernardí de Siena i sant Vicent Ferrer. Pel que fa a l'estil de la predicació, cal parar esment que Giordano da Pisa, tot i ser fidel al dictat de les artes praedicandi, presenta com a novedós l'ús del vulgar en la predicació als laics, que ja devia ser comuna a la Toscana des de la fi del segle xiII, però només a l'inici del Trecento a Florència. Giordano elaborava els sermons seguint la lògica aristotèlica i la filosofia de sant Tomàs d'Aquino (Palermo 2016), sense tenir en ment la formació d'un possible destinatari no massa avesat a la teologia, per tal com presenta un discurs més acadèmic, basat en recursos de l'oratòria sacra que repeteixen idees, paraules i construccions sintàctiques, de manera reiterada. Segons Delcorno $(1975,29)$ el seu objectiu és «piegare una dottrina di tipo universitario ad un preciso ed ambizioso programma di volgarizzazione», per tal com el seu públic és sempre escollit, capaç de seguir un sermó universitari d'erudició tomística.

REVISTA VALENCIANA DE FILOLOGIA / I I I (20I9) p. 345-362 ANNA ISABEL PEIRATS NAVARRO

Les febleses femenines en Giordano da Pisa, Bernardi de Siena i sant Vicent Ferrer / 347 
És evident que Giordano da Pisa tenia coneixements de teologia, ciència, filosofia, així com un gust literari exquisit, d'inspiració en Dant, pel to i la musicalitat, tot i l'àmplia distància entre la creació literària i la predicació; nogensmenys, hi té cabuda la constant referència a la medicina, als negocis del moment, així com a la reforma de la moralitat i dels costums, on no és absent l'exemplum, ${ }^{2}$ com a punt d'unió entre l'escolàstica i la teologia popular.

Bernardí de Siena, d'altra banda, destaca també per l'ús del vulgar, però mostra un estil diferent dels sermons erudits de Giordano da Pisa, basats únicament en exposicions teològiques. Bernardí destaca per la vivesa en l'oratòria, l'eloqüència i la naturalitat, des d'una original retòrica de la senzillesa (Palermo: 2016), a més del fet que partia de l'ideal de fer-se entendre pel públic i endinsar-se en el cor dels receptors. Emprava el dialecte senés, ja que preferia la parla popular, els refranys, les imatges de la vida quotidiana, amb narracions morals, anècdotes... A més, sabia arribar al nivell del poble, per la qual cosa el seu realisme no arribava a ser ofensiu o burlesc, sinó que estava adaptat a les necessitats dels oients. Tractava la importància i els beneficis de la predicació, els vicis, la immoralitat, el luxe i les supersticions, considerats el mal del moment, amb una manera commovedora, mitjançant la qual argumentava els càstigs que s'esdevindrien del judici diví.

En tercer lloc, sant Vicent Ferrer destaca per l'ús del vulgar, el valencià, en aquest cas, de la mateixa manera que Giordano da Pisa i Bernardí de Siena. En els nombrosos sermons conservats i anotats pels reportadors, sant Vicent mostra un estil fidel també a les artes praedicandi, quant a recurrència a un tema, extret de la Sagrada Escriptura, l'ordre en l'exposició i en la dilatatio del sermó, així com un to sovint burlesc i ofensiu, sobretot quan es refereix als delits carnals, els vicis de la luxúria i la vanitat del món, en especial, així com la desmesura en els costums, el vestir, la falta de fe, la necessitat d'acudir a escoltar els seus sermons, participar en la missa... El frare valencià, des de

2 Una de les principals aportacions de l'oratòria medieval és l'ampli ventall de petites històries, llegendes, anècdotes que contenen una lliçó moral, els exemples, o les metàfores ja usades pels pares llatins però adaptades ara com a element de diversió del relat, fet que ben sovint eclipsava el propòsit didàctic. Sobre el concepte d'exemplum en sant Vicent cal destacar la classificació i estudi dels exemples duta a terme en l'estudi d'Almazan (1967).

REVISTA VALENCIANA DE FILOLOGIA / I I I (20I9) p. 345-362

ANNA ISABEL PEIRATS NAVARRO

Les febleses femenines en Giordano da Pisa, Bernardí de Siena i sant Vicent Ferrer / 348 
la superioritat en l'ús de la paraula, pretenia infondre la por pel Judici Final i, doncs, la necessitat d'una conversió, en una societat a la qual pretenia imposar una necessària reforma de la moralitat; sant Vicent partia d'una voluntat de fer-se entendre pels seus receptors, pel poble en general, no per un públic escollit, com Giordano da Pisa, al qual s'adreçava sovint des de més distància que Bernardí de Siena. El discurs vicentí s'allunya del que es podria considerar un sermó didàctic (Grande: 2006-2008), atés que es presentava amb l'embolcall d'un estil força reiteratiu, farcit de recursos que aporten dramatisme i intensitat a la predicació, com ara les onomatopeies, les repeticions constants, les semblances, l'exhortació i la interrogació retòrica. És constant als sermons el recurs a l'auctoritas, així com dels personatges de l'Antic i del Nou Testament que destaquen per l'exercici de les virtuts, oposades als vicis, entre els quals sant Vicent té especial fixació, com Giordano da Pisa i Bernardí de Siena, en la luxúria, sobretot en l'adulteri fora del matrimoni, així com la vanitat i la supèrbia.

\section{Les febleses femenines en Giordano da Pisa, Bernardí de Siena i sant Vicent Ferrer}

El fet que Déu va crear primer l'home i, com a conseqüència, va formar la primera dona és motiu clar d'argumentació en les summes teològiques medievals; així, S. Bonaventura, pren les epístoles paulines per demostrar que l'home està fet a imatge de Déu, però no així mateix la dona (II Sent., d. XVI, q. II). Al costat d'Aristòtil (De gen. anim., II, c. 3) i la tesi que la dona és un mas occasionatus, sant Tomàs d'Aquí veu la inferioritat de la dona com un principi indiscutible (ST, I, q. 92) i estableix una distinció entre dos tipus de subordinació, servil i econòmica.

Tenint en compte que ja Tertul-lià va afirmar que cada dona és una Eva, ${ }^{3}$ es desprén la tesi, àmpliament difosa en tota la tradició medieval, que les dones

3 «Et Evam te esse nescis? Vivit sententia Dei super sexum istum, in hoc saeculo: vivat et reatus necesse est. Tu es diaboli janua, tu es arboris illius resignatrix, tu es divinae legis prima desertrix, tu es quae eum persuasisti» (De cultu feminarum, PL I, 1305).

REVISTA VALENCIANA DE FILOLOGIA / I I I (2OI9) p. 345-362

ANNA ISABEL PEIRATS NAVARRO

Les febleses femenines en Giordano da Pisa, Bernardi de Siena i sant Vicent Ferrer / 349 
són porta del diable i garantia de perpetuació de la sentència pronunciada per Déu en el paradís terrenal. D'aquestes successores d'Eva caldrà defugir i evitar la temptació, els perills de la carn, així com prevenir la imaginació desmesurada en els homes, a partir de la devaluació de l'element femení i de la disciplina moral que infonien els sermons dels predicadors, per tal d'evitar caure en el mal del delit mundà.

\section{Giordano da Pisa}

Per a Giordano da Pisa, seguint la Summa de sant Tomàs d'Aquí (I, q. 5) existeixen tres tipus de bé: el bé honest, el bé útil i el bé delitable, i remarca que els delits mundans i carnals són tots deshonests: «e dicono i savi che in tutti i diletti carnali e mondani è si congiunta la vergogna e'l vituperio [...]. Vedi di bevitori, degli ebriachi, che pigliano più diletti, overo de'carnal» (1305-1306, predica 21, p. 109). Els delits del món, per a Giordano, impedeixen l'home arribar al seu fi i enfosquen l'enteniment; per exemple, dormir massa és pecat:

Il troppo dormire bene è peccato, chi potesse stare sanza dormire sarebbe meglio che dormire... E però che i diletti del mondo obscurano lo'ntendimento e sono cosè nocivi, per questa ragione tutti sono vietati. E eziandio sarebbe vietato quello del matrimonio, se non fosse per tre beni che.ne nascono, cioè fides, proles et sacramentum. Non dico fede di Dio, ma fede tra moglie e marito, che tengano fedaltà l'uno a l'altro, che non si congiunga nullo con altro (1305-1306, predica 21, p. 110).

L'únic possible remei per a Giordano, per tal que se superen els delits corporals és el dejuni, no menjar ni dormir massa, fins i tot com a remei si per massa excessos s'ha introduit una serp en el cos humà (Maldina: 2011, p. 147), com a símil que el dimoni, representat per la serp, en no trobar de què alimentar-se, veurà la seua força reduïda:

REVISTA VALENCIANA DE FILOLOGIA / I I I (20I9) p. 345-362

ANNA ISABEL PEIRATS NAVARRO

Les febleses femenines en Giordano da Pisa, Bernardi de Siena i sant Vicent Ferrer / 350 
La dieta si è il digiuno, a modo che ssi caccia il serpente del corpo. Adiviene quando alcun'otta altri dorme co la bocca aperta, che ccia entra la serpe, e va in ventre, e llà vuole mangiare; se tu mangi avrà che mangiare ella, nutricheralla, ella ci starà volentieri [...], Ma si digiuni è mistieri che ssi ni esca, quando non trova da mangiare. E però a que'cotali è datol molto consiglio pur del digiunare. A questo modo si caccia il demonio, di fare dieta e abstinenzia de le cose del mondo: se ttu le pur usi, e non ne vouli fare alcuna dieta, in tutto questo mondo non è cosa che così notrichi il demonio come questa, non astegnendoti da le cose temporali, onde questa dieta si è uno tòrre l'arma a'demoni. (13051306 , predica 79, p. 380)

Qui es deixa portar per la temptació del dimoni s'aparta de Crist, i fins i tot estableix una semblança entre els diversos tipus de verí de la serp i els diversos tipus de pecats mortals, a través de l'episodi bíblic de Nm 21. En un dels exemples, Giordano da Pisa argumenta que qui segueix Crist es veu alliberat de totes les mossegades verinoses del dimoni-serp:

E sì come tutti coloro che gustavano quel serpente erano liberi dalle morsure e da'veleni de'serpentegli, così chi gusta e contempla Cristo nella croce è liberato da tutte le tentazioni e morsure de'dimoni, e de gli aversari (1993, Esempio 204).

D'acord amb l'instint luxuriós, que condueix a l'adulteri, Da Pisa estableix una comparació entre el pecador i l'hidròpic, de qui el remei és l'abstinència. L'hidròpic, com més menja i beu, més es corrompen els humors i es converteixen en flema (tal com era comú considerar des de la tradició galènica). Amb l'exercici reiterat de menjar i beure més creix el mal de l'hidròpic i té més set, tal com ocorre amb el pecador. Els béns del món esdevenen humors corruptes. Així, el luxuriós mai no es veu sadollat de pecat carnal, i com més en fa, pitjor és per a ell. El més òptim per a aquest luxuriós és abstenir-se de les coses vanes del món (1305-1306, predica 23, p. 121), ja que qui té set de luxúria voldria estar amb totes les dones del món, i no es

REVISTA VALENCIANA DE FILOLOGIA / I I I (2OI9) p. 345-362 
veuria mai sadollat de pecar: "onde quegli c'ha sete di lussuria correbbe, se potesse, usare con tutte le femine del mondo, non si sazierebbe de'peccati, ma mal suo grado, ché non può: non ha natura, né virtù da.cciò» (13051306, predica 45, p. 233).

Per a Giordano la vida de la meretriu és tota pecat, tant pel que fa al vestir com al parlar, quan pronuncia paraules deshonestes, quan menja, és a dir, mai no deixa de pecar. Però no peca quan fa almoina o quan dejuna; en aquesta actuació concreta, seguint la Summa d'Alexandre d'Hales (inq. IV, tractat 2, q. 3), no incorre en cap mal:

Dice santo Paolo: ciò che.ssi fa fuori di fede, tutto è peccato; onde la vita de'pagani è tutta peccato, come quella de'demoni, che continuamente peccano. E che peccati sono questi? Tutti mortali. Così è la vita de'mali cristiani tutta peccato, la vita de la meretrice, tutta peccato. Quando compera i vestimenti, quando dice parole disoneste, quando mangia, che'l fa tutto per peccare $[. .$.$] ma quando la meretrice dà limosina, overo ora o$ digiuna, o cotali cose, non pecca (1305-1306, predica 76, p. 371).

De la resta de dones, Giordano cita sant Pau com a autoritat, ${ }^{4}$ amb el tòpic que la dona romanga en silenci a l'església, que no interprete la paraula de la Sagrada Escriptura, que escolte i que assimile la paraula de Déu: «stea la femina ne la Chiesa, non sia ardita di favellare o d'interpretare parola di santa scrittura. Si che alle femine è tolto in tutto e per tutto, salvo che l'udire, onde vuole che odano, ma tacciano» (1305-1306, predica 28, p. 141).

4 Sant Pau va ser el primer a marcar en els seus escrits la inferioritat descriptiva de la dona i, per tant, la superioritat de l'home, al qual ha de ser subjecta. Com a signe de subordinació, s. Pau presenta algunes afirmacions lapidàries com el «mulieres in ecclesiis taceant» (I Cor 14, 34) o l'obligació de les dones de resar cobertes d'un vel: «omnis autem mulier orans aut prophetans non velato capite deturpat caput autem» (I Cor 11, 5), ritus hereus del culte hebreu.

REVISTA VALENCIANA DE FILOLOGIA / I I I (20I9) p. 345-362

ANNA ISABEL PEIRATS NAVARRO

Les febleses femenines en Giordano da Pisa, Bernardi de Siena i sant Vicent Ferrer / 352 


\section{Bernardí de Siena}

El sermó de Bernardí de Siena, en un altre vessant, se centra especialment en la importància de l'exegesi i de la catequesi dels problemes concrets de la realitat quotidiana. En aquest sentit, Bernardí creu que la paraula s'adreça a una institutio moralis que té en compte, en primer lloc, l'individu, i tracta els problemes importants de la societat: administració, justícia, política, ètica..., a més d'aspectes basats en l'educació de la dona jove, la vida en família i el matrimoni.

Tenint en compte que Déu vindrà el jorn del Judici Final i portarà en la seua mà un llibre obert, el llibre de la vida (predica 2, p. 135), Bernardí destaca quatre raons per les quals enviarà el seu judici al món (predica 5, p. 214): per la mala vida de la gent; per trair la seua paciència; per la prosperitat nostra; per la nostra simulació de bondat. Pel que fa al primer motiu, la mala vida, Bernardí aconsella les dones, abillades amb les cues llargues dels vestits, el mal ús que això comporta:

O donna, che porti la coda, io pure tal voglio dire: se tu la portarai, tu farai pur danno a te. In mal punto ti metti indosso tale vestito, imperò che elli sarà cagione di molta pena nell'altro mondo all'anima tua, e anco forse in questo (1427, predica 3, p. 158).

Els sermons de Bernardí no tenen un to ofensiu contra les dones, tot $\mathrm{i}$ que, òbviament, estan immersos en el context de devaluació femenina que imperava en tota la tradició medieval. Crida l'atenció el sermó en què Bernardí alludeix a la creació d'Adam i Eva, atés que Déu va crear Adam i després Eva (tal com llegim en Gn 2,7; 21-22), i no la va crear del cap de l'home, ni dels peus, sinó del mig, per significar que la dona no és cap de l'home, no ha d'estar per damunt del marit; tampoc no ha d'estar subjugada al marit, per sota, com una esclava. Per aquest clar objectiu, Déu va formar Eva del mig i va crear mascle i femella, perquè volia reservar les dues espècies:

E anco vedi donde elli creò la donna: non la creò del capo dell'uomo, ne anco de piedi, ma creolla del mezzo, pure per misterio, a significare che

REVISTA VALENCIANA DE FILOLOGIA / I I I (2OI9) p. 345-362

ANNA ISABEL PEIRATS NAVARRO

Les febleses femenines en Giordano da Pisa, Bernardi de Siena i sant Vicent Ferrer / 353 
la donna non sia capo dell'uomo. Oh, ella sta male, quando sta ella di sopra all'uomo. Anco vedi che non la volse cavare de'piedi, a dinotare che l'uomo non die aviliare la sua donna: elli la die tenere come donna, e non come schiava. E però dico che elli la cavò e formolla del mezzo, acciò che fussero pari, ma pure trata d'Adamo. Non fece così delle bestie (1427, predica 18 , p. 509).

I fent prevaler l'honor i la dignitat de la dona, Bernardí aconsella les dones estar atentes als matrimonis per diners o per interés, ja que si la unió conjugal està fonamentada en el dot de la dona, els marits s'estimaran més els diners. I al mateix temps aconsella les dones en el vestir:

Io farei mettare una usanza, che tutte le donne andassero vestite a uno modo, come vanno le donne romane, che tutte vanno vestite di pannolino, per loro orrevolezza hanno in dosso e in capo tutte il pannolino bianco, così le donne di quelli prencipi, come l'altre donne (1427, predica 19, p. 543).

El consell, per tant, és no casar-se amb algú que estime més els diners que a elles mateixes. No obstant això, Bernardí és conscient de la importància essencial del matrimoni en la vida social del moment, per tal com feia possible la continuïtat de la família, alhora que implicava un fort nexe d'unió conjugal des del punt de vista econòmic i polític. La dona, per a Bernardí, passava per tres estaments: verge, casada i vídua, dels quals el segon estat, la dona casada (en edat de maridar), era considerada com el menor dels tres estats (predica 3, p. 171).

Quan s'adoctrinava a les joves, l'objectiu que es pretenia aconseguir era assegurar l'honor i la reputació de la dama casada. En aquest sentit, Bernardí aconsella les dones acudir als sermons, ja que si l'ànima és freda s'ha de reescalfar amb la paraula de Déu (predica 3, p. 160). Com es pot percebre, Bernardí no es mostra ofensiu amb les dones, atés que els reconeix les tasques domèstiques, i els recomana ordre en totes les seues accions:

REVISTA VALENCIANA DE FILOLOGIA / I I I (20I9) p. 345-362 ANNA ISABEL PEIRATS NAVARRO 
[...] tutte le cose che si fanno, vogliono ordine e sollecitudine. E però, o donna, pigli l'ordine, che se tu hai a cuociare la carne, quando tu vieni alla predica, fa'che tu la será tu l'abbi comprata, e fa'che tu ti levi la mattina a sovana, e che tu la ponga a fuoco, e schiumala bene; e poi ti veste, e sarà mezza cotta prima che tu venga, e poi a riscaldarla [...] Chi fa miglior pane, o una che abbi sollecitudine, o una che non vi pensi? Che ha sollecitudine (1427, predica 4, p. 187).

A més a més, la dona ha de ser amada i apreciada per les seues virtuts morals, no per la seua bellesa o pel fet de pertànyer a una bona família, sinó que ha de prevaldre el fet de ser una dona honesta, sàvia i que engendre fills. Així, de la mateixa manera que el sol il·lumina el món, seguint Ecl 26, 21, la dona il.lumina la casa (predica 19, p. 559).

Respecte al matrimoni, Bernardí argumenta que Déu va ordenar el sagrament per tal d'omplir la glòria del paradís i de la vida eterna (doctrina que es pot contemplar també en sant Gregori, PL 76 o en sant Agustí, PL 40). El matrimoni va ser ordenat en l'Antic Testament i confirmat en el Nou Testament per quatre testimonis: evangèlic, apostòlic, autèntic i testimoni per miracle. I el primer miracle que Jesucrist va fer va ocórrer en unes noces, en què va convertit l'aigua en vi, acte que significa l'abundància de tenir descendència, tal com és preceptiu al matrimoni (predica 19, p. 551).

I respecte a l'adulteri, o el simple fet de freqüentar les meretrius, Bernardí argumenta que es peca greument contra el sisé manament i afirma amb contundència que aquest és el major pecat, unir-se a una altra persona estant casats (predica 20). Basant-se en aquest fet constatable, l'actitud de la dona per tal de no deixar-se portar per l'apetit desordenat ha de ser contundent: cada vegada que el marit vulga fer ús de matrimoni sense intenció d'engendrar, que no obeïsca, perquè es tracta d'un apetit desordenat (predica 20). En el vessant oposat, segons Bernardí, la dona ha d'obeir el marit quan reclama el seu dret (debitum coniugalem) a unir-se en matrimoni; altrament, pecaria la dona i a més la mare d'aquesta, per no haver ensenyat a bastament les seues obligacions matrimonials (Santonja: 2015, p. 268).

REVISTA VALENCIANA DE FILOLOGIA / I I I (20I9) p. 345-362 
Les dones han de ser, segons Bernardí, un bon exemple a imitar, si pretenen que el marit les crega: que dejunen, que facen abstinència de menjars delicats, que regulen l'ànsia de menjar, que romanguen hores de dormir en vigília, dedicades a l'oració, que assistisquen als sermons, a la missa, que no usen vils vestits; que no vagen massa per les cases d'altres; que facen obres de misericòrdia, sobretot confortar els tribulats, visitar malalts, almenys oferint bones paraules; és a dir, que tinguen bons costums, amb la qual cosa donaran un bon exemple al marit (predica 20, p. 602).

Pel fet de fer un excessiu ús de matrimoni, segons Bernardí, s'esdevenen tres mals: la malaltia, la mort la impossibilitat d'engendrar en un futur (predica 21 , p. 611), atés que s'abreuja la vida i es peca mortalment. I pel fet d'unir-se sexualment el matrimoni quan la dona està embarassada, seguint Alexandre d'Hales, a partir d'una facècia de Poggio Bracciolini (1983, p. 332) té perill de perdre la criatura. I addueix Bernardí l'exemple del camp, que per sembrar massa no es tenen fruits (predica 21, p. 613).

Per a Bernardí existeixen tres pecats mortals, doncs: la supèrbia, la vanitat i la luxúria. I en el sermó 37 Bernardí arremet amb màxima virulència contra la dona que porta determinats vestits, amb els quals demostra ser una meretriu. Caldria cremar a qui porta tal vestit i a qui ho permet. El consell és clar: portar vestits amb honestedat:

A proposito vo'dire che la donna che porta il vestimento meretricio [...] Non hai più sentimento? Ma tu, madre o padre, come le lassi o fai portare? Non cognosci tu che questo non è vestimento da donne, ma più ratto da meretrice: io non dico che tu se'una meretrice, ma dico che tu pari meretrice per la disonesta portatura tua [...] Doh, ditemi, non sete voi cristiane? O se voi sete cristiane, perché non seguitate voi la dottrina cristiana? Forse voi volete parere e non essare. Doh, pigliate e usate i buoni essempli, e portate i vostri vestimenti con onestà, e non voliate che di voi si possa dire altro che tutto bene, si in atti e anco in fatti. (1427, predica 37, p. 1071)

REVISTA VALENCIANA DE FILOLOGIA / I I I (20I9) p. 345-362

ANNA ISABEL PEIRATS NAVARRO

Les febleses femenines en Giordano da Pisa, Bernardi de Siena i sant Vicent Ferrer / 356 


\section{Sant Vicent Ferrer}

En un pla oposat, quant a intensitat i to, la predicació de sant Vicent Ferrer, frare dominicà, presenta una societat que ha de viure conscienciada de la imminència del judici particular de les ànimes, tot just traspassada l'existència en la terra. La temàtica constant en què es concentren els sermons del dominic valencià és força repetitiva $\mathrm{i}$ es basa en uns eixos constants: la reforma dels costums civils i religiosos, la conversió, la predestinació, així com la crítica als jueus i la imminència del Judici Final. Per tant, el discurs del sant no és original quant a temàtica, sinó que el seu punt novedós rau en el fet que es presenta com una persona d'autoritat inqüestionable, avalat per les autoritats, pel poder de Benet XIII i el rei Ferran d'Antequera, aspectes que asseguraven la seua total credibilitat (Grande: 2006-2008, p. 170). Segons el sant valencià caldrà dur una vida virtuosa, on és essencial donar almoina, fer penitència front a la imminència d'una mort pròxima; és a dir, el seu discurs és eficient, segons sant Vicent, perquè parteix de l'objectiu concret de fer prevaldre la por i la necessitat d'una conversió espiritual. Després de la mort, segons Sant Vicent en el cel sant Pere estarà encarregat dels homes i sant Miquel de les dones, i tots dos rebran les ànimes de bon grat, les abraçaran i les besaran amb alegria (I, p. 54); però si no es fan bones obres, no hi haurà bona rebuda ni honor. Quan una persona mor i acudeix al judici de Déu, Jesucrist obre el llibre de la consciència, tal com apuntava també Bernardí, on hi ha dues cartes: en una, a la dreta, i amb lletres d'or, escriu el bé; mentre que en l'altra, amb tinta negra i a l'esquerra, escriu el mal (I, 61).

Quan una dona vol donar a llum, Crist envia un bon àngel en el seu nom, perquè vaja allà on aquella dona ha d'infantar de manera imminent, per tal que la criatura no perille. I l'àngel preservarà de tot mal aquest infant durant tota la vida en la terra (I, p. 63). Tot i aquesta tramesa privilegiada i personalitzada per a cada infant que naix, hi ha dones «malastrugues» que maten els fills per cobrir el seu pecat, i tenen les mans plenes de sang pel crim que han comés (I, p. 24); és a dir, hi ha de les dones «ribaldes», segons fra Vicent, que ofeguen les criatures (I, p. 38), fins i tot algunes d'elles ja han parit una o dues vegades

REVISTA VALENCIANA DE FILOLOGIA / I I I (2OI9) p. 345-362 ANNA ISABEL PEIRATS NAVARRO

Les febleses femenines en Giordano da Pisa, Bernardi de Siena i sant Vicent Ferrer / 357 
abans del matrimoni. Els excessos i impulsos naturals de les dones porten els infants que alleten a la mort $\mathrm{i}$ algunes dones maten els fills de quatre maneres: «mas no deu hom matar en IIII maneres: primo, per venjança; secundo, per avarícia; $3^{\circ}$ per necligència, e açò fa per les dones quan aleyten la creatura chiqua, que per culpa sua no muyre, $4^{\circ}$ per vergonya: que la creatura no sie matada perquè lo peccat sie cubert» (Sanchis ed. 1934: II, p. 212).

I quan sant Miquel cridarà: «surgite, mortui, venite ad iudicium», esta veu l'oiran no sols els cristians, sinó també els moros, els jueus i tots els altres infidels, així com els infants que moren en el ventre de les mares, bé per ballar massa la mare i matar la criatura, bé per por a descobrir el pecat. I l'infant, que ha mort sense batejar, cridarà «justícia» (I, p. 39). La criatura que no està batejada no és filla de Déu per gràcia, però «si és batejada, hoc!» (I, p. 69).

Sant Vicent mostra un interés a pronunciar-se en contra dels vicis capitals, en especial de la luxúria. Per menjar i beure massa es cau en els plaers de la carn, que segons el frare valencià són "esllenegalls de l'ànima». A les dones "podrides», que beuen vi, els put l'alé (I, p. 219). I increpa els capellans perquè s'abstinguen de beure a la taverna, de jurar i de tenir concubina (I, p. 83), des d'una sàtira contra els capellans luxuriosos: «E dien alguns que quiny pecat és luxúria en lo prevere o religiós. En persona layca que és solta, que no és en matrimoni, és lo pus petit peccat de luxúria; mas en capellà o religiós és lo major» (I, p. 84). Un prevere que vol viure bé és aquell que: «no vol jugar als daus, ni beure en taverna, ni portar coltell, ni anar a caçar, ni jurar de Déu, ni vol dones, e vol dir bé ses hores, e a la missa ben apparellat» (I, p. 94).

I si la luxúria és un pecat capital contra el qual arremet el frare dominicà, molt més carrega l'èmfasi en referir-se a l'adulteri, partint del vincle sagrat del matrimoni. Sant Vicent beneeix el matrimoni entre marit i muller devots (III, p. 249) i posa l'exemple del matrimoni de Joaquim i Anna, que no podien tenir fruits del seu matrimoni, però no anaven a endevins ni a fetilleres, ni eren infidels. El matrimoni, per a sant Vicent, és la cinquena columna que sustenta l'Església (II, p. 28) i representa l'Encarnació del Fill de Déu amb la nostra humanitat (I, p. 190); l'adulteri, per tant, és una heretgia, per tal com Crist no pot prendre una altra humanitat diferent de la pròpia; és a dir, no hi

REVISTA VALENCIANA DE FILOLOGIA / I I I (20I9) p. 345-362 ANNA ISABEL PEIRATS NAVARRO

Les febleses femenines en Giordano da Pisa, Bernardi de Siena i sant Vicent Ferrer / 358 
ha dos Jesucristos, sinó un de sol, fet paral-lel amb la persona que representa el matrimoni (I: 65): «adúlters, hòmens de matrimoni que no serven la fe a sa companya» (1413: 213).

\section{Conclusions}

Amb tot, i des de les tres mostres de predicació presentades i confrontades pel que fa al vessant de la luxúria, de l'adulteri fora del matrimoni i, en especial, del tractament sobre les febleses femenines, dels tres estils de sermons coetanis, de Giordano da Pisa, Bernardí de Siena i sant Vicent Ferrer podem concloure que tots tres predicadors opten per l'ideal lingüístic del vulgar en la predicació. Tots tres arremeten contra els mals de l'ànima, sobretot la luxúria (amb la forma concreta de l'adulteri), la supèrbia i la vanitat, des de l'argumentació que els sagraments, sobretot el baptisme i el matrimoni, adquireixen. Tots tres consideren els sagraments com a remeis als vicis del món. I usen l'exemplum amb lleugeres divergències: en Da Pisa, amb un estil més universitari, per tal com recorre a les fonts hagiogràfiques i bíbliques, sobretot; en Bernardí i en sant Vicent, més quotidià i, de vegades, basat en l'experiència per auctoritas als exempla extrets de les vides de sants, així com les dones virtuoses del Nou Testament, com és el cas de la samaritana, la dona cananea o Maria Magdalena, entre d'altres.

Quant a la consideració de la dona, Da Pisa no carrega la sàtira contra la dona per se, i empra un estil més sobri; sí que arremet, nogensmenys, contra les meretrius o contra les dones que cometen adulteri o es deixen portar pel vici de la luxúria. Bernardí de Siena, d’altra banda, destaca per la visió més positiva, el to comprensiu i els consells que dedica a les dones, a les quals els reconeix les tasques domèstiques i argumenta la dignitat intrínseca de la dona des de la mateixa creació, tot i que és conscient dels perills de les dones que es deixen embogir per les modes en el vestir i pels pentinats seductors. Sant Vicent, en darrer terme, parteix d'una visió de la dona que s'emmarca totalment en la consideració des del punt de vista misogin: Eva és la portadora del mal en el

REVISTA VALENCIANA DE FILOLOGIA / I I I (20I9) p. 345-362

ANNA ISABEL PEIRATS NAVARRO

Les febleses femenines en Giordano da Pisa, Bernardi de Siena i sant Vicent Ferrer / 359 
món. Sant Vicent critica, amb virulència, no aconsella, sinó que empra un to burlesc i ofensiu contra les dones, i insisteix a denunciar el luxe del vestir i del pentinat, amb paraules carregades d'invectiva i vehemència.

Tots tres predicadors convergeixen, no obstant les divergències d'estil, en un mateix ideal: la reforma de la societat i dels costums. Es tracta de tres estils diferents, adaptats sempre a la preceptiva de les artes praedicandi, amb un mateix missatge apologètic, que pretén adoctrinar les masses més cultes, en Giordano Da Pisa; aconsellar el poble en general i reconduir-lo a una vida fructífera en bones obres, en Bernardí de Siena; o atemorir i conscienciar, en sant Vicent Ferrer, des del to ofensiu i força imperatiu i reiteratiu, de la imminència del Judici Final i la necessitat d'una conversió espiritual, com a resultat d'una vida virtuosa. 


\section{Bibliografia}

Almazan, V. (1967) «L'exemplum chez Vincent Ferrier», RF, 79, pp. 288-345.

Aquino, sant Tomàs (1998) Suma de Teología, Madrid, BAC, 5 vols.

Aristòtil (1965 ed.) De generatione animalium (Drossaart Lulofs ed. lit.), Oxford, Scriptorum Classicorum Bibliotheca Oxoniensis.

Bracciolini, P. (1995) Facezie (ed. S. Pittalunga), Roma, Garzanti.

Delcorno, C. (1974) «Retorica e funzionalità nelle "Introduzioni” di Fra Giordano da Pisa", Lettere Italiane, 26, 2, Casa Editrice Leo S. Olschki, pp. 141-164.

Eiximenis, F. (1983) Lo Crestià (ed. A. Hauf), Barcelona, Edicions 62 - La Caixa.

FABBRi, L. (1996) «Trattatistica e pratica dell'alleanza matrimoniale», dins M. DE GIorgio; C. Klapisch Zuber (eds.) Storia del matrimonio, Roma-Bari Laterza, pp. 91-117.

Ferrer, sant Vicent (ed. 1932-1988) Sermons (ed. J. Sanchis Sivera i G. Schib), Barcelona, Barcino, 6 vols.

- (ed. 1929) Quaresma de Sant Vicent Ferrer, predicada a València l'any 1413 (ed. J. Sanchis Sivera), Barcelona, Institució Patxot.

Frenguelli, G. (2009) «Il serpente del metallo, il badalischio e il camaleone. Giordano da Pisa e i bestiari», L'imagine riflessa, XVIII, pp. 169-198.

Gaffuri, L.; Quinto, R. (2002) Predicazione e società nel Medioevo. Riflessione etica, valori e modelli di comportamento, Pàdua, Centro Studi Antoniani.

Grande, M. T. (2006-2008) «Las raíces de la eficacia del discurso homilético de fray Vicente Ferrer en la campaña de predicación castellana de 1411-1412», Revista de Historia Medieval, 15, pp. 165-188.

Hales, A. (1948) Summa Theologica seu sic ab origine dicta Summa Fratris Alexandri, Ad Claras Aquas, Quaracchi.

Hassig, D. (1995) Medieval Bestiaries. Text, image, ideology, Cambridge-Nova York, Cambridge University Press.

Heisenbach, C. de (2009 ed.). Dialogus Miraculorum (N. Nöges i H. Schneider eds.), Turnhout, Brepols.

Lausberg, H. (1999) Manual de retórica literaria, Madrid, Gredos.

Lewis, R. (1978) De miseria condicionis humane, Athens, The Chaucer Library; The University of Georgia Press.

Maldina, N. (2011) «La serpe in corpo. Per il bestiario di Giordano da Pisa», Erebea. Revista de Humanidades y Ciencias Sociales, 1, pp. 137-156.

Martí de Barcelona, P. (1936) «L'Ars praedicandi de fra Francesc Eiximenis», Homenatge a Antoni Rubió Lluch, II, pp. 304-340.

Murphy, J. J. (1974) Rhetoric in the Middle Ages. A histoy of rhetorical therory from saint Augustine to the Renaisssance, Los Angeles-Berkeley-Londres,: University of California Press.

REVISTA VALENCIANA DE FILOLOGIA / I I I (20I9) p. 345-362

ANNA ISABEL PEIRATS NAVARRO

Les febleses femenines en Giordano da Pisa, Bernardi de Siena i sant Vicent Ferrer / 36I 
Palermo, M. (2016) «Serialità e iterazione in Giordano da Pisa e Bernardino da Siena», Lingue e Stile, LI, pp. 169-193.

Patrologiae Cursus Completus Series Latina [PL]. (ed. J.P. Migne, 1841-1855). 217 vols., [Consultat en <http://www.roger-pearse.com/weblog/patrologia-latina-pl-volumes-available-online $>$ ].

PISA, G. da (1974 ed.) Quaresimale fiorentino 1305-1306 (ed. Carlo Delcorno), col. "Autori Classici e Documenti di lingua Pubblicati dall'Accademia della Crusca», Florència, G. C. Sansoni.

- (1993 ed.) Racconti esemplari di predicatori del Due e Trecento (ed. G. Baldassarri i G. Varanini), Roma, Salerno Editrice.

Roig, J. (ed. 2010) Spill de Jaume Roig (ed. A. I. Peirats), València, AVL. 2 vols+CD.

Santonja, P. (2015) «La situación de las mujeres y el matrimonio en la Edad Media y en los siglos XVI y XVII", Cuadernos para Investigación de la Literatura Hispánica, 40, pp. 267-286.

Siena, B. da (1989 ed.) Prediche volgari sul campo di Siena, 1427 (ed. C. Delcorno), Milà, Rusconi, 2 vols.

REVISTA VALENCIANA DE FILOLOGIA / I I I (20I9) p. 345-362 